\title{
Anti-Inflammatory Activity of Cream Type O/W with Concentration Variation of Essential Oils of Clove (Syzigium aromaticum)
}

\author{
Nining Sugihartini*, Aina Fatkhil Haque, and Tedjo Yuwono \\ Faculty of Pharmacy, Universitas Ahmad Dahlan, Yogyakarta 55166, Indonesia
}

\begin{abstract}
Clove essential oil (Syzigium aromaticum) has been proven as anti-inflammatory agent. Formulation in the cream type O/W preparations was required to be utilized by the community. The aims of this research was to determined activity of cream as anti-inflammatory with concentration variation of essential oil. Cream was made by melting method with concentration variation of clove essential oil: $2.5 \% ; 5 \% ; 10 \%$. The cream was evaluated for anti-inflammatory activities by using animal test BALB/c strain of mice that previously has been induced inflammation with crotton oil. The results showed that increasing concentrations of clove essential oils tended to increase the thickness of skin folds, thickness of the epidermis, the number of inflammatory cells and the number of cells with COX-2 expression. The optimal concentration of essential oils in cream type O/W as anti-inflammatory was $2.5 \%$.
\end{abstract}

Keywords: Clove Essential Oil, Cream Type O/W, Anti-Inflammatory.

\section{INTRODUCTION}

Inflammation was a response to injury, penetration of infectious compounds, antigens or cell damage that indicate the presence of harm to the body or disease. Therefore this process was a body defense response that will induce the body's efforts in minimizing tissue damage. ${ }^{1,2}$ The body's defense mechanism was a complex sequence such as dilatation of the arteria, capillaries and veins with increased vascular permeability, fluid exudation including plasma proteins as well as leukocyte movements to inflammation sites to neutralize and eliminate harmful stimulus. ${ }^{1}$

In inflammation there was increasing activity of several enzymes such as protein tyrosine kinase, protein kinase C, phosphodiesterase, phospholipase A2, lipoxygenases, and cyclooxygenase (COX). These enzymes are enzymes that play a role in the activation of endothelial cells and some other important cells that play an important role in the occurrence of inflammation. ${ }^{3}$ Long-lasting inflammation can cause some pathological conditions such as bacterial sepsis, rheumatoid arthritis and inflammation of the skin. Skin inflammation can be demonstrated by increasing of skin thickness, which may indicate an increase in vascular permeability, edema, and swelling to the dermis layer and proliferation of epidermal keratinocytes. ${ }^{4}$

Clove essential oil (Syzygium aromaticum) contains eugenol which has activity as anti-inflammatory, local anaestetic, analgetic, antibacteria, antioxidant, antihalitosis, aphrodisiac. ${ }^{5-9}$

*Author to whom correspondence should be addressed.
The clove essential oil was included in the Myrtaceae family with the largest component was eugenol of $70-96 \%$. $6,10,11$ The previous study showed the mechanism of eugenol (4-allyl2-methoxyphenol as an antioxidant and anti-inflammatory by inhibits prostaglandin synthesis and neutrophil chemotaxis. ${ }^{12}$ The other study showed the mechanism of eugenol as antiinflammatory was by inhibiting the synthesis of prostaglandins and neutrohil chemotaxis, ${ }^{8,12}$ inhibiting the NF-kB factor that will activate tumor factor factor- $\alpha$ (TNF- $\alpha$ ) tumor necrosis factor, ${ }^{13,14}$ inhibited the expression of cyclooxygenase (COX)-2 in macrophage-stimulated lipopolysaccharide $(\mathrm{LPS})^{15}$ and reduced production leucotrienes as mediataor inflammataion. ${ }^{5}$

Based on the potential of eugenol in clove essential oil as anti-inflammatory, it was necessary to develop the appropriate dosage form. Inflammatory processes can occur in the skin. This was because the skin was the first barrier of the body to the environment, the first protector in case of damage and trauma due to pathogen. ${ }^{3}$ Delivery through the skin was an alternative drug delivery system that can provide benefits to prevent first pass effects and gastric irritation. ${ }^{15}$ It has been investigated in green tea delivery systems. ${ }^{16}$ Some nonsteroidal anti-inflammatory drugs have been also formulated in topical preparations to avoid systemic effects such as disorders gastrointestinal, cardiac and toxicity of the kidneys. ${ }^{17}$

The formulation of cream from herbal as anti-inflammatory was done by the other researcher. ${ }^{18,19}$ In this study clove essential 
oil will be formulated into $\mathrm{O} / \mathrm{W}$ cream dosage form with various concentrations. Cream was a semi-solid preparation that has soft consistency and widely was used in cosmetics. Cream contains a lot of water that gives a sense of cold, which can reduce the heat that occurs in inflammation. Water also serves as an enhancer, which can increase the permeability of the drug through the skin without causing irritation or permanent damage to the skin's surface structure. ${ }^{20}$

The optimal concentration of clove essential oil in O/W cream in this study will be determined by performing a series of tests on the anti-inflammatory properties in vivo. The parameters that was used to evaluate anti-inflammatory activity are the epidermal thickness, the number of inflammatory cells and the number of cells with COX-2 expression. This study was expected to produce topical pharmaceutical preparations of $\mathrm{O} / \mathrm{W}$ cream that was effective as anti-inflammatory.

\section{MATERIAL AND METHOD}

\subsection{Material}

Materials in this research were clove essential oil from UII and ingredients of the cream with pharmaceutical degree obtained from Bratacho Chem (vaseline, nipagin, nipasol, stearic alcohol, na lauryl sulphate, propylene glycol and water). Test animals used adult male mice, BALB/c strains (25-30 g) from the Integrated Research and Testing Laboratory (LPPT), UGM.

\subsection{Tools}

Tools in this research were glassware and Olympus microscope.

All of the research procedures have obtained the ethical approval letter from the Research Ethics Committee numbered 011508062 in 2015.

\subsection{Preparation of Cream Formulation}

Cream of clove essential oil was made with reference to the results of previous research as presented in Table I. ${ }^{21}$ Cream was made by melting method which beguns by melting the oil-soluble material (mixture 1), i.e., vaseline, nipagin, alcohol stearate, on waterbath at $75{ }^{\circ} \mathrm{C}$. Meanwhile for water-soluble ingredients (mixture 2) also melted at the same temperature in different containers, i.e., nipasol, na lauryl sulfate and propylene glycol on waterbath. Then the two mixtures were mixed on a warm mortar and stirred until homogeneous. Finally clove essential oil was added in the cream in a cold temperature.

\subsection{Anti-Inflammatory Test}

This study used 7 treatment groups, each consisting of 6 mice. The seven groups included the normal control group and 6 groups

Table I. Formula of cream clove essential oil.

\begin{tabular}{lc}
\hline Ingredients & Amount \\
\hline Clove essential oil & $2.5 \%, 5 \%, 10 \%$ \\
Vaseline & 25 \\
Nipagin & 0.025 \\
Nipasol & 0.015 \\
Stearic alcohol & 25 \\
Na lauryl sulphate & 1 \\
Propilen glycol & 12 \\
Aquades & Ad 100 \\
\hline
\end{tabular}

that was given inflammatory induction with croton oil. After induction of inflammation each of groups received cream base treatment (base control), the anti-inflammatory cream from market (positive control), 2.5\% concentration clove essential oil in cream $(\mathrm{F} 1), 5 \%$ concentration clove essential oil in cream (F2), $10 \%$ concentration clove essential oil in cream (F3), non-treated group (negative control), respectively.

The procedure of induction were firstly the back of mice was shaved. After 24 hours, the back of mice was dropped with $0.1 \mathrm{ml}$ of croton oil $(4 \%)$ and then after 30 minutes was applied the cream base, the anti-inflammatory cream from market (positive control), $2.5 \%$ concentration clove essential oil in cream (F1), 5\% concentration clove essential oil in cream (F2) and 10\% concentration clove essential oil in cream (F3) as much as $100 \mathrm{mg}$ daily for 3 days. Furthermore, mice were sacrificed with cervical dislocations. The skin tissue is then removed and immersed in $10 \%$ formalin for the preparation of histopathologic preparations with hematoxylin eosin (HE) and COX-2 immunohistochemistry performed according to standard methods in Pathology Laboratory, Faculty of Medicine, UGM and Anatomical Pathology Laboratory, RS. Dr. Sardjito, Yogyakarta. ${ }^{21}$

The amount of inflammatory cell counts was performed on histopathologic preparations painted with HE. Number of inflammatory cells was calculated on three planes view in each slice of skin tissue per animal test. Calculation of inflammatory cells can be known in the presence of blackish brown spots. The thickness of epidermis was measured by the average distance between the deepest epidermis layers and the outermost measured from the three field view in each slice of skin tissue per animal test. The number of cells expressing COX-2 was done by $400 \times$ magnification on three viewing planes in each slice of skin tissue per animal test, based on the number of cells showing the brown color on the cytoplasm or its core. Calculations are performed after skin tissue preparations are given immunohistochemical staining using COX-2 polyclonal antibodies. Microscopic observations and measurements were done using a microscope that has been connected with optilab.

\section{RESULTS AND DISCUSSION}

In this study data were gotten from macroscopic observation parameter based on the thickness of skin fold (Fig. 1) and microscopic observation parameters based on epidermal thickness, the amount of inflammation cell and cell number with COX-2 expression (Table II) (Fig. 2). The results of statistical analysis from data of thickness of skin fold showed significant difference

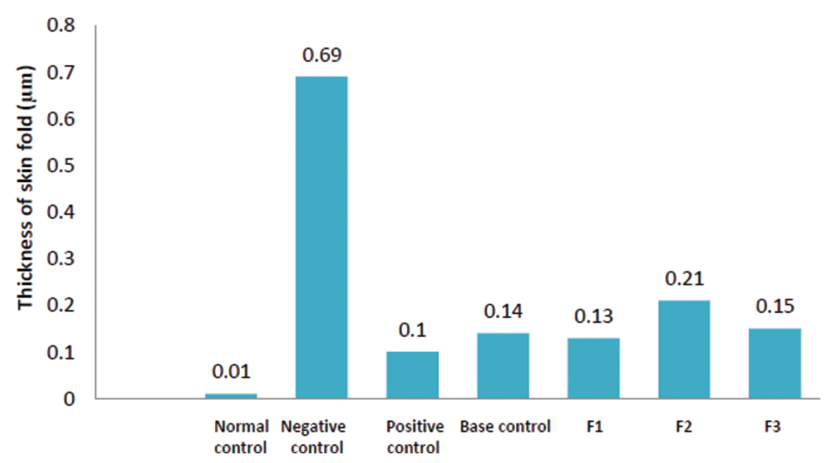

Fig. 1. Thickness skin fold of each groups. 
Table II. The results of the epidermal thickness, the number of inflammatory cells and the number of cells with COX-2 expression at various treatments $(N=6)$.

\begin{tabular}{lccc}
\hline Group & $\begin{array}{c}\text { Epidermis } \\
\text { thickness }(\mu \mathrm{m})\end{array}$ & $\begin{array}{c}\text { The number of } \\
\text { inflammatory } \\
\text { cells }\end{array}$ & $\begin{array}{c}\text { The number of } \\
\text { cells with } \\
\text { COX-2 expression }\end{array}$ \\
\hline Normal control & $34,70 \pm 59$ & $2507 \pm 98$ & $1,08 \pm 0,69$ \\
Negative control & $78,78 \pm 10$ & $3790 \pm 87^{*}$ & $2,45 \pm 0,51^{*}$ \\
Positive control & $71,97 \pm 17$ & $1423 \pm 51$ & $1,93 \pm 0,35$ \\
Base control & $145,638 \pm 42$ & $2303 \pm 62$ & $2,92 \pm 0,18$ \\
F1 & $128,293 \pm 12 @ \&$ & $2098 \pm 88^{\#+}$ & $1,66 \pm 0,60 @$ \\
F2 & $143,257 \pm 29 @ \&$ & $2441 \pm 73^{\#}$ & $2,22 \pm 0,56 @$ \\
F3 & $118,132 \pm 22^{@ \&}$ & $3217 \pm 81^{\# @}$ & $2,42 \pm 0,36 @$ \\
\hline
\end{tabular}

Information: *Significant difference with normal control, \# significant difference with negative control, @ significant difference with normal control, \& significant difference with positive control, ${ }^{+}$significant difference with F2 and F3.

between normal control and negative control. This means induction with crotton oil has led to increase skin folds. The results of the microscopic parameters was similar with the macroscopic parameter. Data show that the thickness of the epidermis, the amount of inflammatory cells and the number of cells with
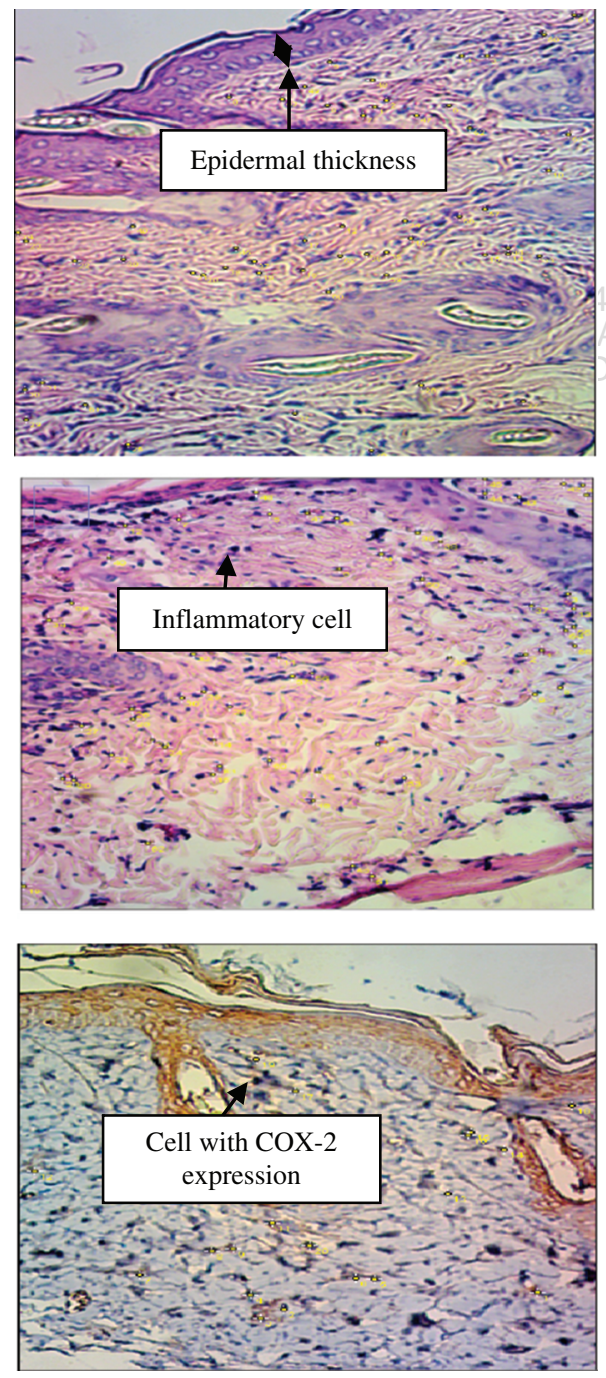

Fig. 2. The microscopic picture of epidermal thickness, inflammatory cells and cells with COX-2 expression at $400 \times$ magnification.
COX-2 expression in normal control was less than negative control. Significant differences were seen in data the number of inflammatory cells and number of cells with COX-2 expression. Its means that induction with crotton oil caused inflammation. Croton oil was known to have irritant and inflammation properties so the oil was selected as an inflammatory inductor. ${ }^{22}$ Croton oil has a mechanism to activate the phospholipase A2 which then removes arachidonic acid from the cell membrane. These arachidonic acids are then metabolized to prostaglandins and leukotriene. ${ }^{23}$

Normal control (No treated), Negative control (treatment with crotton oil 4\%), Positive control (treatment with crotton oil 4\% and then cream anti-inflammatory from market), Base control (treatment with crotton oil $4 \%$ and then base cream), F1 (treatment with crotton oil $4 \%$ and then F1), F2 (treatment with crotton oil $4 \%$ and then F2), F3 (treatment with crotton oil $4 \%$ and then F3).

The positive control (antiinflammatory preparations from the market) can decrease the thickness of skin fold that most closely to normal controls. It was similar with microscopic parameters especially data of epidermis thickness and the number of inflammatory cells. The active ingredient in positive control was diclofenac sodium. Diclofenac commonly was used as topical anti-inflammatory. The mechanism of diclofenac was by inhibitting of activity of cyclooxygenase- 1 and cyclooxygenase- 2 enzyme, thromboxane-prostanoid receptor that influenced to release and up take of arachidonic-acid, lipooxigenase enzyme and activating of oxide-cyclic guanosine monophosphate pathway. Topical diclofenac dosage forms was more effective than the other non-steroidal anti-inflammatory drug. ${ }^{24,25}$

Base control group was used to evaluate the potential of the cream base as anti-inflammatory. Treatment with cream base was also able to reduce the thickness of skin fold and the number of inflammatory cells. It means the ingredients in base have the antiinflammatory activity. On the other hand the epidermal thickness and the number of cells with COX-2 expression of base control was higher than negative control. It was needed the other data from next research to support the possibility of ingredients in base as anti-inflammatory.

The cream with $2.5 \%$ concentration of clove essential oil can reduce the thickness of skin fold higher than the others concentration. It was similar with data of the number of inflammatory cells and the number of cells with COX-2 expression. This activity could reduce the number of inflammatory cells so there was significant difference with negative control. The activity of cream with $2.5 \%$ concentration of clove essential oil at the paramter of the number of inflammatory cells was significant difference with the F2 (5\% concentration of clove essential oil) and F3 (10\% concentration of clove essential oil). It meaned that this concentration has the best activity as the anti-inflamamtory based on the data of the number of inflammatory cells. However there was significant different with normal control in data of epidermis thickness and the number of cells with COX-2 expression and positive control in data of epidermis thickness. The activity of cream with $2.5 \%$ clove essential oil concentration has not been able to restore the inflamed skin to normal condition. This activity was also still smaller than the anti-inflammatory dosage forms on the market based on data epidermis thickness. The significant difference with normal control and positive control also occur in F2 and F3.

The treatment with cream type $\mathrm{O} / \mathrm{W}$ with variation concentrations of clove essential oil can reduce the number of 
inflammatory cells (there was significant difference) and the number of cells with COX-2 expression (there was not significant difference) when was compared with the negative control. It showed eugenol in essential oil of clove has potential as antiinflammatory. Mechanism action of eugenol in the clove essential oil as an antioxidant and anti-inflammatory was by inhibition of prostaglandin synthesis and neutrophil chemotaxis. ${ }^{8,12}$ In addition, it has been proven that the phenolic antioxidants can inhibit the expression of cyclooxygenase (COX)-2 in lipopolysaccharide (LPS) stimulated makrofag ${ }^{8}$ and can inhibit the activity of factor-kB in activating TNF- $\alpha$. Its as agents involved in the process of inflammation and carcinogenesis in various processes pathophysiology, ${ }^{13}$ transcription factors that are important in regulating inflammatory response and expression of inflammatory cytokines and stimulate cells activity in smooth muscle which has a major role in designing the inflammatory process. On the other hand, COX as an enzyme converts arachidonic acid into prostanoid. There are two isoforms of COX, namely COX-1 as constitutive that resides in most types of cells, and COX-2, which appears as growth factors, cytokines and LPS through the activation of transcription factors such as NF-kB in various cells. ${ }^{14}$

However the decreasing of the number of inflammatory cells and the number of cells with COX-2 expression have not provided the same conditions with normal control because there were significant differences. Except for data on the number of inflammatory cells in which the treatment group with concentrations of $2.5 \%$ and $5 \%$ had a smaller number of inflammatory cells compared with normal control. The activity was not same with activity of $\mathrm{Na}$ Diclofenac, which was active ingredient in the anti-inflammatory cream from market. In all three parameters the treatment group with cream still has higher an epidermal thickness, the number of inflammatory cells and the number of cells with COX-2 expression than the positive control.

The increasing concentration of essential oils in cream raised epidermal thickness, the number of inflammatory cells and the number of cells with COX-2 expression significantly. The increasing of the number of inflammatory cell at the F3 (10\% concentration of clove essential oil) gived significant difference with normal control. This was probably due to the activity of eugenol as active compound in clove essential oil as enhancer. ${ }^{26}$ Essential oil could be used as enhancer. ${ }^{27}$ Essential oil contains terpenes that can be used as enhancers. ${ }^{28,29}$ It was because of their high ability to improve penetration with a skin irritant effect and low systemic toxicity at low concentrations of $1-5 \%$. Terpen works by altering the fat structure of the stratum corneum thus increasing the polar drug's diffusion coefficient in the membrane. ${ }^{30}$ One of the enhancer mechanisms by damaging the lipid tissue may cause a certain concentration to cause side effects on the skin. ${ }^{31}$ Essential oil as enhancer did not cause skin toxicity but some times caused mild irritation. ${ }^{32}$

\section{CONCLUSION}

The optimum concentration of clove essential oil in cream type $\mathrm{O} / \mathrm{W}$ as anti-inflammatory was $2.5 \%$.
Acknowledgment: This research was financially supported by Grant Research scheme Penelitian Tim Pascsarjana from Kemenristekdikti in 2014/2015.

\section{References and Notes}

1. G. R. M. Lima, C. A. Montenegro, C. L. F. Almeida, P. F. Athayde-Filho, J. M. Barbosa-Filho, and L. M. Batista, International Journal of Molecular Science 12, 2692 (2011).

2. A. L. Souto, J. F. Tavares, M. S. Da Silva, M. F. F. M. Diniz, P. F. De AthaydeFilho, and J. M. B. Filho, Molecules 16, 8515 (2011)

3. P. Rathee, H. Chaudhary, S. Rathee, D. Rathee, V. Kumar, and K. Kohl, Inflammation and Allergy—Drug Targets 8, 229 (2009).

4. S. M. Al-Reza, J. Yoon, H. Kim, J. Kim, and S. Kang, Food and Chemical Toxicology 48, 639 (2009).

5. V. Nikoni, S. Ostadhadi, A. Baktiarian, E. Abbasi-Gonjani, S. HabibianDehkordi, M. Rezaei-Rosham, et al., Pharmanutrition 5, 52 (2017).

6. R. Mekhtriat, K. Jannageon, S. Pikulkaew, and S. Okonogi, Asian Journal of Pharmaceutical Science II, 231 (2016)

7. G. K. Kamatou, I. Vermaak, and A. M. Viljoen, Molecules 17, 6953 (2012)

8. Y. Murakami, M. Shoji, S. Hanazawa, S. Tanaka, and S. Fujisawa, Biochem. Pharmacol. 66, 1061 (2003).

9. De Sá, R. da Silveira, L. N. Andrade, R. R. B. de Oliveira, and D. P. de Sousa, Molecules 19, 1459 (2014).

10. M. H. Alma, M. Ertas, S. Nitz, and H. Kollmannsbergs, BioResouces 2, 265 (2007).

11. N. Nurdjannah, Perspektif 3, 61 (2009)

12. Q. S. Ma and K. Kineer, J. Biol. Chem. 277, 2477 (2002)

13. G. B. N. L. Chainy, S. K. Manna, M. M. Chaturvedi, and B. B. Aggarwal, Oncogene 19, 2943 (2000)

14. F. D'Acquisto, T. luvone, L. Rombola, L. Sautebin, M. Di Rosa, and R. Carnuccio, FEBS Lett. 418, 175 (1997).

15. D. Bhowmik, H. Gopinath, B. Pragati, S. Duraivel, and K. P. Sampath, The Pharma Journal 1, 12 (2012)

16. J. C. Maroon, J. W. Bost, and A. Maroon, Surgical Neurology International 1 (2010). $201823 \cdot 11 \cdot 53$

17. R. L. Barkin, America Journal of Therapeutics (2012)

18. S. Fatma, R. Zaman, N. Haider, S. Shanti, and A. Alam, Journal of Ayurveda and Integrative Medicine XXX, 1 (2017).

19. J. Yang, Y. A. Xiong, S. J. Xiao, and Y. S. Xu, Chinese Herbal Medicines 9, 176 (2017).

20. J. Swarbrick and J. Boylan, Encyclopedia of Pharmaceutical Technology, Marcel Dekker Inc., New York, USA (2002), Vol. 3.

21. N. Sugihartini, Optimasi Komposisi Enhancer dan Emulgator pada Formulasi Krim Fraksi Etil Asetat Ekstrak Teh Hijau (Camellia sinensis, L) sebagai Sediaan Topikal Antiinflamasi, Disertasi, Program Pascasarjana Fakultas Farmasi UGM, Yogyakarta, (2013), pp. 78-79.

22. M. Lan, P. Wan, Z. Y. Wang, and X. L. Huang, Zhong Yao Cai Journal 35, 1105 (2012)

23. B. Shah, A. Seth, and K. Maheshwari, Research Journal of Medicinal Plant 5, 101 (2011)

24. C. F. Goh and M. E. Lane, International Journal of Pharmaceutics 473, 607 (2014).

25. J. L. Zilfener, S. Leal, and P. E. Fournier, Annuals of Physical and Rehabilitation Medicine 53, 278 (2010).

26. N. S. Sheth and R. B. Mistry, Journal of Applied Pharmaceutical Science 1, 96 (2011)

27. J. Wang, Y. Lan, H. Li, Y. Zhang, Q. Zhang, Y. Cao, and Q. Wu, Journal of Traditional Chinese Medical Sciences 1, 109 (2014).

28. J. H. Tak and M. B. Isman, Industrial Croops and Products 101, 29 (2017)

29. T. N. Barradas, J. P. Senna, S. A. Cardoso, S. Nicoli, C. Padula, P. Santi, et al., European Journal of Pharmaceutics and Biopharmaceutics 116, 38 (2017).

30. N. Kanikkanan, K. Kandimalla, S. Lamba, and M. Singh, Current Medicina Chemistry 6, 593 (1999)

31. L. Fox, M. Gerber, J. Plessis, and J. Hamman, Molecules 16, 10507 (2011)

32. I. Vanish, A. Ahad, M. Aqil, and S. P. Agarwal, Asian Journal of Pharmaceutical Sciences 9, 260 (2014). 